\title{
Evaluation of water suspension effect on spectral light attenuation in Novosibirsk Reservoir
}

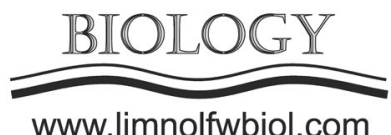

www.limnolfwbiol.com

\author{
Akulova O.B.*, Bukaty V.I. \\ Institute for Water and Environmental Problems SB RAS, Molodezhnaya St., 1, Barnaul, Altai Krai, 656038, Russia
}

\begin{abstract}
The paper presents the measurement data (August $20-22,2019$ ) on spectral light attenuation in the Novosibirsk Reservoir waters in the range from 400 to $800 \mathrm{~nm}$. In different sampling stations, attenuation (calculated on the natural logarithmic base) varied within $4.6-25.9 \mathrm{~m}^{-1}$. Relative transparency $(42-140 \mathrm{~cm})$ was measured using a Secchi disk. To assess the effect of water suspension on total attenuation, we calculated its relative spectral contribution and other main optically active components of water, i.e. yellow substance, chlorophyll $a$ and pure water. Yellow substance and suspension showed the maximum contribution to light attenuation in the water from all 10 sampling stations of the reservoir. The spectral contribution of suspension was $30-60 \%$ in the range of $430 \mathrm{~nm}$, $39-71 \%$ at $550 \mathrm{~nm}$ and $33-64 \%$ at $670 \mathrm{~nm}$, respectively. The suspension was the second optically active component affecting spectral light attenuation.
\end{abstract}

Keywords: spectral light attenuation coefficient, suspension, yellow substance, chlorophyll $a$, pure water, Novosibirsk Reservoir

\section{Introduction}

Water suspension is one of the most important optically active components of any natural or manmade water body. Along with yellow substance (YS), chlorophyll $a$ and pure water, suspension has a significant effect on total light attenuation (Kopelevich, 1983; Reinart et al., 2004; Mankovsky and Sherstyankin, 2007; Mankovsky, 2011; Onderka et al., 2011; Shuchman et al., 2013; Levin, 2014; Korosov et al., 2017; Shi et al., 2017; Churilova et al., 2018). Therefore, its optical characteristics dependent on particles' size, quantity, material, shape and orientation require a thorough study. Water suspension is often understood as a set of large (with a diameter of 0.5 $\mu \mathrm{m}$ to $1 \mathrm{~mm})$, small $(0.45-1 \mu \mathrm{m})$ and colloidal $(0.001$ - $0.1 \mu \mathrm{m})$ particles, which consist of terrigenous (mineral) and biological (organic) fractions (Clavano et al., 2007). The relationship between suspended substance concentrations and spectral light attenuation directly depends on the composition and properties of suspension, namely, a size, a shape and a refractive index of particles. All this determines the regional features of the water body under study.

The aim of this work is to evaluate the water suspension effect on spectral light attenuation based on the calculated experimental data, i.e. the relative spectral contribution of main optically active water components of the Novosibirsk Reservoir waters in the summer of 2019.

\section{Material and methods}

The study object is Novosibirsk Reservoir; by the water area, it is the largest (regardless of the Irtysh) in the $\mathrm{Ob}$ River basin manmade reservoir constructed for the multipurpose use, i.e. water supply (mainly drinking water), hydropower, irrigation, fish farming, and recreation. The results of 10 processed and analyzed water samples taken by a bathometer from the surface water layer of Novosibirsk Reservoir became the basis for our study. For observations on August 20 - 22, 2019, we used a research vessel. Table 1 shows numbers, names and coordinates of sampling stations.

Hydro-optical characteristics of water samples were measured in the laboratory using a single-beam spectrophotometer PE-5400UF operating in the mode of measuring spectral water transparency (transmittance) with further calculations of spectral light attenuation $\varepsilon(\lambda)$ in the wavelength range of $400-800 \mathrm{~nm}$ with a step of $30 \mathrm{~nm}$. Spectral light absorption by yellow substance $\kappa_{y s}(\lambda)$ was defined after measuring spectral transparency of the water purified from suspension by filtration through the «Vladipor» type MFAS-OS-1 membranes with a pore diameter of $0.22 \mu \mathrm{m}$. Overall, 240 measurements of spectral water transparency were carried out. The $\varepsilon(\lambda)$ (at the natural logarithmic base) value was calculated according to the formula

$$
\varepsilon(\lambda)=(1 / L) \cdot \ln (1 / T(\lambda))
$$


derived from the Booger's law, where $L$ is the cuvette length, $\mathrm{T}(\lambda)=I(\lambda) / I_{0}(\lambda)$ - the transparency (transmittance) in relative units, $I(\lambda), I_{0}(\lambda)$ - the intensity of transmitted and incident light, respectively, $\lambda$ - the wavelength of light. The absolute error of $\varepsilon(\lambda)$ is induced by the spectrophotometer instrument error during transmittance measurement $(\Delta T=0.5 \%)$ and the measurement error of a cuvette length. In the experiment, we used cuvettes with a length $L=50$ $\mathrm{mm}$. The maximum absolute error in defining the light attenuation coefficient was $0.1 \mathrm{~m}^{-1}$.

The concentration of chlorophyll $a$ in acetone extracts of phytoplankton algae was found through a standard spectrophotometric method according to the standard GOST 17.1.4.02-90. Relative transparency of $Z$ was measured using a Secchi disk.

The relative spectral contribution of optically active components of water (suspension, yellow substance, chlorophyll and pure water) to $\varepsilon(\lambda)$ was calculated using a modified semi-empirical spectral model of light attenuation (Akulova, 2015), which was first proposed in Kopelevich, 1983, as follows:

$$
\begin{gathered}
\varepsilon(\lambda)=\kappa_{c h l}(\lambda)+\kappa_{y s}(\lambda)+\sigma_{m o l}(\lambda) \\
+\sigma_{s}(\lambda)+\kappa_{p w}(\lambda)
\end{gathered}
$$

where $\kappa_{c h l}(\lambda)$ and $\kappa_{y s}(\lambda)$ - spectral absorption by chlorophyll and yellow substance, respectively, $\sigma_{\text {mol }}(\lambda)$ - spectral scattering by pure water, $\sigma_{s}(\lambda)$ spectral dispersion by suspension, $\kappa_{p w}(\lambda)$ - spectral absorption by pure water. The calculated attenuation in the formula (1) does not contain the attenuation coefficient of pure water $\varepsilon_{p w}(\lambda)=\kappa_{p w}(\lambda)+\sigma_{m o l}(\lambda)$. In the formula (2), we summed up the $\varepsilon(\lambda)$ values obtained from spectrophotometer measurements with $\varepsilon_{p w}(\lambda)$ taken from the reference data (Kopelevich, 1983; Levin, 2014). follows:

Rate of chlorophyll absorption was calculated as

$$
\kappa_{c h l}(\lambda)=\kappa_{s p . c h l}(\lambda) \cdot C_{c h l}
$$

Where $C_{c h l}$ is the concentration of chlorophyll $a$, $\mathrm{mg} / \mathrm{m}^{3}, \kappa_{s p . c h l}(\lambda)-$ the specific chlorophyll absorption, $\mathrm{m}^{2} / \mathrm{mg}$ (Kopelevich, 1983). For calculations of $\kappa_{p w}(\lambda)$, we used the tabular data of Levin (2014), whereas for $\sigma_{\text {mol }}(\lambda)$ - Kopelevich (1983).

According to the expression (2), spectral light attenuation is described via a three-parameter model. In contrast to the previous studies (where parameter $\sigma_{s}(\lambda)$ is determined experimentally, and $\kappa_{y s}(\lambda)$ is the difference between the measured $\varepsilon(\lambda)$ and the sum of other parameters), we propose an alternative approach. Since the $\kappa_{y s}(\lambda)$ parameter was identified experimentally, spectral scattering of suspension $\sigma_{s}(\lambda)$ can be found from the expression (2) with the following formula:

$$
\begin{aligned}
\sigma_{s}(\lambda) & =\varepsilon(\lambda)-\left[\kappa_{c h l}(\lambda)+\kappa_{y s}(\lambda)\right. \\
& \left.+\sigma_{m o l}(\lambda)+\kappa_{p w}(\lambda)\right]
\end{aligned}
$$

\section{Results and discussion}

Hydro-optical characteristics (spectral parameters of light attenuation $\varepsilon(\lambda)$ and light absorption by yellow substance $\kappa_{y s}(\lambda)$ as well as relative transparency $Z$ in the surface layer of the water differed significantly during the study period. The spectral light attenuation coefficient made up $4.6-25.9 \mathrm{~m}^{-1}$ within $400-800$ $\mathrm{nm}$ (August $20-22$, 2019). For instance, $\varepsilon(\lambda)$ varied as $10.9-22.4 \mathrm{~m}^{-1}$ at the wavelength $\lambda=430 \mathrm{~nm}, 7.0$ - $15.9 \mathrm{~m}^{-1}$ at $\lambda=550 \mathrm{~nm}$ and $5.7-12.7 \mathrm{~m}^{-1}$ at $\lambda=670$ $\mathrm{nm}$. These wavelengths were chosen because maximal light absorption by chlorophyll fell on $\lambda=430$ and 670 $\mathrm{nm}$, whereas the greatest solar radiation - at $\lambda=550$ $\mathrm{nm}$, which was taken into account under optical device development and used as a marker in hydro-optical studies.

Relative transparency $Z$ measured using a Secchi

\begin{tabular}{|c|c|c|}
\hline Sampling date & Station number (name) & Coordinates \\
\hline 20.08.2019 & 1.2 (Kamen-on-Ob, a midpoint of the reservoir section) & $53.4629932 \mathrm{~N} 81.2320987 \mathrm{E}$ \\
\hline 21.08.2019 & 3.2 (Maletino, a midpoint of the reservoir section) & $54.0253884 \mathrm{~N} 81.2435273 \mathrm{E}$ \\
\hline 21.08.2019 & 4.2 (Spirino, a midpoint of the reservoir section) & $54.0738719 \mathrm{~N} 81.3344964 \mathrm{E}$ \\
\hline 21.08 .2019 & 5.1 (Ordynskoye-Nizhnekamenka, left bank) & $54.2112316 \mathrm{~N} 81.5434117 \mathrm{E}$ \\
\hline 21.08.2019 & 5.3 (Ordynskoye-Nizhnekamenka, right bank) & $54.1926605 \mathrm{~N} 81.5436392 \mathrm{E}$ \\
\hline 22.08.2019 & 6.3 (Borovoye-Bystrovka, right bank) & $54.3352643 \mathrm{~N} 82.3308600 \mathrm{E}$ \\
\hline 22.08.2019 & 7.3 (Leninskoye-Sosnovka, right bank) & $54.4108884 \mathrm{~N} 82.5331697 \mathrm{E}$ \\
\hline 22.08.2019 & 8.2 (Berdsky gulf, Agroles, a midpoint of the reservoir section) & $54.4554623 \mathrm{~N} 83.90216 \mathrm{E}$ \\
\hline 22.08.2019 & 9.2 (Berdsky gulf, Rechkunovka, a midpoint of the reservoir section) & $54.4735297 \mathrm{~N} 83.0420651 \mathrm{E}$ \\
\hline 22.08.2019 & 10.2 (head reach, near the HPP dam) & $54.4954354 \mathrm{~N} 82.5811518 \mathrm{E}$ \\
\hline
\end{tabular}
disk was in the range of $42-140 \mathrm{~cm}$. Its maximum was recorded on the right bank of the Leninskoye-Sosnovka section (station 7.3).

Table 1. Sampling stations and their coordinates in the surface layer of Novosibirsk Reservoir (August 2019) 
Table 2. Spectral contribution of water components (\%) to light attenuation in the surface layer of Novosibirsk Reservoir (August $20-22,2019$ )

\begin{tabular}{|c|c|c|c|c|c|}
\hline \multirow[b]{2}{*}{$\begin{array}{c}\text { Wavelength } \\
\text { of light } \lambda, \mathrm{nm}\end{array}$} & \multicolumn{3}{|c|}{ Light absorption } & \multirow{2}{*}{$\begin{array}{l}\text { Light scattering } \\
\frac{\sigma_{s}(\lambda)+\sigma_{m o l}(\lambda)}{\varepsilon(\lambda)}\end{array}$} & \multirow[b]{2}{*}{$\begin{array}{l}\text { Light } \\
\text { attenuation } \varepsilon, \mathrm{m}^{-1}\end{array}$} \\
\hline & $\frac{\kappa_{p w}(\lambda)}{\varepsilon(\lambda)}$ & $\frac{\kappa_{y s}(\lambda)}{\varepsilon(\lambda)}$ & $\frac{\kappa_{c h l}(\lambda)}{\varepsilon(\lambda)}$ & & \\
\hline \multicolumn{6}{|c|}{ station $1.2\left(C_{a}=17.6 \mathrm{mg} / \mathrm{m}^{3}\right)$} \\
\hline $\begin{array}{l}430 \\
550 \\
670 \\
\end{array}$ & $\begin{array}{l}0.1 \\
0.5 \\
4.6 \\
\end{array}$ & $\begin{array}{l}55.3 \\
42.8 \\
39.3 \\
\end{array}$ & $\begin{array}{l}8.3 \\
0.9 \\
7.4 \\
\end{array}$ & $\begin{array}{l}36.3 \\
55.8 \\
48.7 \\
\end{array}$ & $\begin{array}{c}16.8 \\
11.9 \\
9.4 \\
\end{array}$ \\
\hline \multicolumn{6}{|c|}{ station $3.2\left(C_{a}=16.9 \mathrm{mg} / \mathrm{m}^{3}\right)$} \\
\hline $\begin{array}{l}430 \\
550 \\
670 \\
\end{array}$ & $\begin{array}{l}0.1 \\
0.5 \\
5.0 \\
\end{array}$ & $\begin{array}{l}50.3 \\
42.3 \\
39.5 \\
\end{array}$ & $\begin{array}{l}9.4 \\
1.0 \\
7.8 \\
\end{array}$ & $\begin{array}{l}40.2 \\
56.2 \\
47.7 \\
\end{array}$ & $\begin{array}{c}14.3 \\
10.4 \\
8.6 \\
\end{array}$ \\
\hline \multicolumn{6}{|c|}{ station $4.2\left(C_{a}=18.7 \mathrm{mg} / \mathrm{m}^{3}\right)$} \\
\hline $\begin{array}{l}430 \\
550 \\
670 \\
\end{array}$ & $\begin{array}{l}0.1 \\
0.3 \\
3.4 \\
\end{array}$ & $\begin{array}{l}33.0 \\
27.6 \\
26.7 \\
\end{array}$ & $\begin{array}{l}6.6 \\
0.7 \\
5.8 \\
\end{array}$ & $\begin{array}{l}60.3 \\
71.4 \\
64.1 \\
\end{array}$ & $\begin{array}{l}22.4 \\
15.9 \\
12.7\end{array}$ \\
\hline \multicolumn{6}{|c|}{ station $5.1\left(C_{a}=8.7 \mathrm{mg} / \mathrm{m}^{3}\right)$} \\
\hline $\begin{array}{l}430 \\
550 \\
670 \\
\end{array}$ & $\begin{array}{l}0.1 \\
0.5 \\
4.6 \\
\end{array}$ & $\begin{array}{l}58.1 \\
44.7 \\
38.3 \\
\end{array}$ & $\begin{array}{l}4.3 \\
0.5 \\
3.7 \\
\end{array}$ & $\begin{array}{l}37.5 \\
54.3 \\
53.4 \\
\end{array}$ & $\begin{array}{c}16.0 \\
11.4 \\
9.4 \\
\end{array}$ \\
\hline \multicolumn{6}{|c|}{ station $5.3\left(C_{a}=10.5 \mathrm{mg} / \mathrm{m}^{3}\right)$} \\
\hline $\begin{array}{l}430 \\
550 \\
670 \\
\end{array}$ & $\begin{array}{l}0.1 \\
0.4 \\
4.1 \\
\end{array}$ & $\begin{array}{l}38.5 \\
33.0 \\
31.7 \\
\end{array}$ & $\begin{array}{l}4.7 \\
0.5 \\
4.0 \\
\end{array}$ & $\begin{array}{l}56.7 \\
66.1 \\
60.2 \\
\end{array}$ & $\begin{array}{l}17.9 \\
13.0 \\
10.4 \\
\end{array}$ \\
\hline \multicolumn{6}{|c|}{ station $6.3\left(C_{a}=6.7 \mathrm{mg} / \mathrm{m}^{3}\right)$} \\
\hline $\begin{array}{l}430 \\
550 \\
670 \\
\end{array}$ & $\begin{array}{l}0.1 \\
0.5 \\
4.8 \\
\end{array}$ & $\begin{array}{l}41.2 \\
38.2 \\
37.0 \\
\end{array}$ & $\begin{array}{l}2.9 \\
0.4 \\
3.0 \\
\end{array}$ & $\begin{array}{l}55.8 \\
60.9 \\
55.2 \\
\end{array}$ & $\begin{array}{c}18.2 \\
11.5 \\
8.9 \\
\end{array}$ \\
\hline \multicolumn{6}{|c|}{ station $7.3\left(C_{a}=6.4 \mathrm{mg} / \mathrm{m}^{3}\right)$} \\
\hline $\begin{array}{l}430 \\
550 \\
670 \\
\end{array}$ & $\begin{array}{l}0.1 \\
0.6 \\
6.7 \\
\end{array}$ & $\begin{array}{l}58.7 \\
51.2 \\
49.2 \\
\end{array}$ & $\begin{array}{l}4.0 \\
0.5 \\
3.9 \\
\end{array}$ & $\begin{array}{l}37.2 \\
47.7 \\
40.2 \\
\end{array}$ & $\begin{array}{c}12.6 \\
8.2 \\
6.5 \\
\end{array}$ \\
\hline \multicolumn{6}{|c|}{ station $8.2\left(C_{a}=13.5 \mathrm{mg} / \mathrm{m}^{3}\right)$} \\
\hline $\begin{array}{l}430 \\
550 \\
670 \\
\end{array}$ & $\begin{array}{l}0.1 \\
0.5 \\
5.0 \\
\end{array}$ & $\begin{array}{l}49.3 \\
43.3 \\
40.6 \\
\end{array}$ & $\begin{array}{l}6.7 \\
0.8 \\
6.3 \\
\end{array}$ & $\begin{array}{l}43.9 \\
55.4 \\
48.1 \\
\end{array}$ & $\begin{array}{c}16.0 \\
10.6 \\
8.6 \\
\end{array}$ \\
\hline \multicolumn{6}{|c|}{ station $9.2\left(C_{a}=10.1 \mathrm{mg} / \mathrm{m}^{3}\right)$} \\
\hline $\begin{array}{l}430 \\
550 \\
670 \\
\end{array}$ & $\begin{array}{l}0.1 \\
0.5 \\
5.5 \\
\end{array}$ & $\begin{array}{l}60.6 \\
51.4 \\
44.3 \\
\end{array}$ & $\begin{array}{l}4.9 \\
0.6 \\
5.1 \\
\end{array}$ & $\begin{array}{l}34.4 \\
47.5 \\
45.1 \\
\end{array}$ & $\begin{array}{c}16.5 \\
10.3 \\
7.9 \\
\end{array}$ \\
\hline \multicolumn{6}{|c|}{ station $10.2\left(C_{a}=4.4 \mathrm{mg} / \mathrm{m}^{3}\right)$} \\
\hline $\begin{array}{l}430 \\
550 \\
670 \\
\end{array}$ & $\begin{array}{l}0.1 \\
0.8 \\
7.6 \\
\end{array}$ & $\begin{array}{l}66.9 \\
60.0 \\
56.1 \\
\end{array}$ & $\begin{array}{l}3.2 \\
0.4 \\
3.1 \\
\end{array}$ & $\begin{array}{l}29.8 \\
38.8 \\
33.2 \\
\end{array}$ & $\begin{array}{c}10.9 \\
7.0 \\
5.7 \\
\end{array}$ \\
\hline
\end{tabular}

The calculated concentrations of chlorophyll $a$ in the surface layer of Novosibirsk Reservoir were within $4.4-18.7 \mathrm{mg} / \mathrm{m}^{3}$, with an average of $11.3 \mathrm{mg} /$ $\mathrm{m}^{3}$. Based on the long-term data, spatial heterogeneity of the chlorophyll content was studied thoroughly in the Laboratory of Aquatic Ecology of IWEP SB RAS (Kotovshchikov, 2018).

Table 2 presents the calculation results of the spectral contribution of the main optically active components of water (suspension, yellow substance, chlorophyll $a$, and pure water) to spectral light attenuation $\varepsilon(\lambda)$ in various sampling stations of Novosibirsk Reservoir. Here, values $\varepsilon(\lambda)$ and $\kappa_{y s}(\lambda)$ are given on the natural logarithmic base.

The result of calculations of relative spectral contribution of optically active water components to light attenuation $\varepsilon(\lambda)$ in the surface layer of Novosibirsk Reservoir in various sampling stations suggests that yellow substance and suspension have the greatest optical effect on total attenuation. The calculations show that yellow substance provides the greatest contribution $(67 \%)$ to light attenuation at $\lambda=430$ 
$\mathrm{nm}$ in the upper reach, nearby the HPP dam (station 10.2). At other sampling stations, the contribution of YS varies within $33-61 \%$. At $\lambda=550 \mathrm{~nm}$, the relative contribution of YS ranges from $28 \%$ (station 4.2 - Spirino, a midpoint of the reservoir section) to $60 \%$ (station 10.2); at $\lambda=670 \mathrm{~nm}$, the HPP dam has the largest YS contribution (56\%). The maximum suspension contribution (over $60 \%$ ) is observed at the station 4.2 (Spirino, a midpoint of the reservoir section) at $\lambda=430 \mathrm{~nm}$, with its increase up to $71 \%$ at $\lambda=550$ nm. At $\lambda=670 \mathrm{~nm}$, the suspension contribution varies from $33 \%$ (station 10.2) to $64 \%$ (station 4.2). Pure water makes an insignificant contribution (less than $0.1 \%$ ) to light attenuation at $\lambda=430 \mathrm{~nm}$ at all stations. However, it increases sharply ( $8 \%$ ) at $\lambda=670 \mathrm{~nm}$. The contribution of chlorophyll at $\lambda=430 \mathrm{~nm}$ reaches from $3 \%$ (station 6.3 - Borovoye-Bystrovka, right bank) to $9 \%$ (3.2 - Maletino, a midpoint of the reservoir section); at $\lambda=550 \mathrm{~nm}$ it is from $0.4 \%$ (stations 6.3 and 10.2) to $1 \%$ (3.2). At $\lambda=670 \mathrm{~nm}$, the maximum chlorophyll contribution is observed at station $3.2(8 \%)$. Molecular light scattering by pure water in the studied spectral range is responsible for a small contribution $(0.1 \%)$.

Thus, suspension in waters of Novosibirsk Reservoir is the second most important optically active component affecting spectral light attenuation.

\section{Conclusion}

The article presents the optical experiment results for assessing water suspension effect on spectral light attenuation obtained during the implementation of a series of complex hydrological studies in the water area of Novosibirsk Reservoir in August 2019. Being one of the most optically active water components able to affect light attenuation (under certain physicochemical conditions), the suspension may serve as an important indicator of water quality. Therefore, further research is of particular importance.

\section{Acknowledgments}

We express our gratitude to Kotovschikov A.V., a senior researcher of the Laboratory of Hydrobiology, IWEP SB RAS for water sampling and the provided measuring data on chlorophyll $a$ and relative transparency determined using a Secchi disk.

The work was carried out within the framework of the Research Program of IWEP SB RAS (project No. AAAAA 17-117041210241-4).

\section{References}

Akulova O.B. 2015. Development of methods and a measuring computer system for assessing ecologically significant hydro-optical characteristics of freshwater reservoirs (by the example of lakes in Altai Krai). Cand. Sc. Dissertation, Institute for Water and Environmental Problems SB RAS, Barnaul, Russia. (in Russian)

Churilova T.Ya., Moiseeva N.A., Latushkin A.A. et al. 2018. Preliminary results of bio-optical investigations at Lake Baikal. Limnology and Freshwater Biology 1: 58-61. DOI: 10.31951/2658-3518-2018-A-1-58

Clavano W.R., Boss E., Karp-Boss L. 2007. Inherent optical properties of non-spherical marine-like particles - from theory to observation. Oceanography and Marine Biology: An Annual Review 45: 1-38.

Kopelevich O.V. 1983. A low-parameter model of the optical properties of sea water. In: Monin A.S. (Ed.), Optika okeana. T.1. Fizicheskaya optika okeana. Moscow, pp. 208-235. (in Russian)

Korosov A.A., Pozdnyakov D.V., Shuchman R. et al. 2017. Bio-optical retrieval algorithm for the optically shallow waters of Lake Michigan. I. Model description and sensitivity/ robustness assessment. Trudy Karel'skogo Nauchnogo Tsentra RAN [Transactions of the Karelian Research Centre of RAS] 3: 79-92. DOI: 10.17076/lim473 (in Russian)

Kotovshchikov A.V., Yanygina L.V. 2018. Spatial heterogeneity of chlorophyll a content in Novosibirsk reservoir. Izvestiya Altayskogo Otdeleniya Russkogo Geograficheskogo Obshchestva [Bulletin AB RGS] 3: 46-52. (in Russian)

Levin I.M. 2014. Low-parametric models of primary optical characteristics of sea water. Fundamental'naya i Prikladnaya Gidrofizika [Fundamental and Applied Hydrophysics] 7: 3-22. (in Russian)

Mankovsky V.I., Sherstyankin P.P. 2007. Spectral model of an indicator of directional light weakening in waters of Lake Baikal in summer. Morskoy Gidrofizicheskiy Zhurnal [Marine Hydrophysical Journal] 6: 39-46. (in Russian)

Mankovsky V.I. 2011. Spectral contribution of components of sea water to an indicator of directional light weakening in the surface water of the Mediterranean Sea. Morskoy Gidrofizicheskiy Zhurnal [Marine Hydrophysical Journal] 5: 14-29. (in Russian)

Onderka M., Rodný M., Velísková Y. 2011. Suspended particulate matter concentrations retrieved from selfcalibrated multispectral satellite imagery. Journal of Hydrology and Hydromechanics 59: 251-261. DOI: 10.2478/ v10098-011-0021-9

Reinart A., Paavel B., Pierson D. et al. 2004. Inherent and apparent optical properties of Lake Peipsi, Estonia. Boreal Environment Research 9: 429-445.

Shi L., Mao Z., Wu J. et al. 2017. Variations in spectral absorption properties of phytoplankton, non-algal particles and chromophoric dissolved organic matter in Lake Qiandaohu. Water 9. DOI: 10.3390/w9050352

Shuchman R.A., Leshkevich G., Sayers M.J. et al. 2013. An algorithm to retrieve chlorophyll, dissolved organic carbon, and suspended minerals from Great Lakes satellite data. Journal of Great Lakes Research 32: 14-33. DOI: 10.1016/j. jglr.2013.06.017 